\title{
SOCIAL ROBLEMS AND PUBLIC IMAGE OF THE HOUSING ESTATES OF 1960's IN SPAIN. AN ANALYSIS OF CASES
}

\author{
Piñeira-Mantiñán María José \\ Mancomunidade da Área Intermunicipal de Vigo \\ e-mail: mariajose.pineira@maiv.org
}

Aldrey-Vázquez José Antonio

Universidad de Santiago de Compostela

\begin{abstract}
The decade of the 1960's in Spain was characterized for period in which there proliferated the construction of housing estates. Though these constructions in a beginning(principle) were constructed in the periphery of the cities nowadays they form a part of the urban consolidated nucleus. They are characterized for having a morfogía in opened apple and in general to receive groups with scanty buying power.
\end{abstract}

Key wods: National Housing Institute, rationalistic town-planning, urban outskirts, social problems.

One of the most serious problems arisen after the Spanish Civil War was the reconstruction of cities and the building of new housing. 200 architects gathered at a meeting agreed that the general policy that should guide this process of reconstruction had to be based on the "building of homes, rather than mere buildings, as homes were central to the growth of minds and the framework giving support to families." The aim was to build the kind of cities that could realise the ideals of falangism, and not isolated housing estates for the working class after an architectural conception that would accentuate class divisions, with buildings highlighting the differences of the people living in them from the rest of society. Ideally, people of different social extractions would live together in the same block of flats. However, this intention to pull down class barriers failed miserably, as well as the townplanning precepts underpinning it, since, as we shall see later, the final result was the extensive building of the housing estates they so much detested.

The Instituto Nacional de la Vivienda or INV, (National Housing Institute), founded in 1939, took charge of passing the building ordinances, dictating the general construction planning, determining the value of leases and arranging for loans to be provided by credit 
institutions, as well as of ensuring compliance with the regulations, and proposing legal reforms.

The purpose of the State was to make it easier for certain entities to find the capital necessary to set in motion the extensive building of state-fostered housing and of all those communal services and road links necessary for adequate living conditions. "State-fostered housing" was understood as housing for a reduced lease included in the scheme of the National Housing Institute (INV). The requirements to benefit from the scheme were the following: being a Spanish national, of legal age and having a trade, job or profession or being a state pensioner. These requirements made it difficult for many people moving from the countryside into towns to access this scheme, as they usually looked for a place to live before finding themselves a job.

Table 1: Classification of state-fostered housing promoted with the help o the INV

\begin{tabular}{|c|c|c|c|}
\hline \multicolumn{2}{|c|}{$\begin{array}{l}\text { State-fostered housing } \\
\text { Built by private promoters in accordance with } \\
\text { public regulations, but with enough profit } \\
\text { margins. }\end{array}$} & \multicolumn{2}{|c|}{$\begin{array}{l}\text { Public housing } \\
\text { Built directly by the public authorities in order } \\
\text { to solve the shortage of accommodation. Houses } \\
\text { were hardly ever built to be let and were more } \\
\text { often than not sold eventually to their occupants, } \\
\text { even to those who had originally opted for a } \\
\text { lease. The majority of them were built during } \\
\text { Franco's regime, mostly during the 1960's and } \\
\text { 1970's. }\end{array}$} \\
\hline $\begin{array}{l}\text { Low-price } \\
\text { housing }\end{array}$ & $\begin{array}{l}\text { Built to eradicate shanty } \\
\text { towns. In general, all public } \\
\text { housing built during the first } \\
\text { half of the } 20^{\text {th }} \text { century fell } \\
\text { under this category. }\end{array}$ & $\begin{array}{l}\text { Reintegration } \\
\text { neighbourhood } \\
\text { units }\end{array}$ & $\begin{array}{l}\text { Housing for low income com- } \\
\text { munities affected by town } \\
\text { planning schemes. }\end{array}$ \\
\hline $\begin{array}{l}\text { State-funded } \\
\text { housing }\end{array}$ & $\begin{array}{l}\text { The Administration finances } \\
\text { directly the builder or promo- } \\
\text { ter. }\end{array}$ & $\begin{array}{l}\text { Controlled } \\
\text { housing estates }\end{array}$ & $\begin{array}{l}\text { Housing estates created with } \\
\text { the aim of preventing unautho- } \\
\text { rised settlements and providing } \\
\text { immigrants with a place to live. }\end{array}$ \\
\hline $\begin{array}{l}\text { Low-rent } \\
\text { housing }\end{array}$ & $\begin{array}{l}\text { Funds go directly towards the } \\
\text { cost of building materials, the } \\
\text { forceful expropriation of } \\
\text { lands and long-term credits. }\end{array}$ & $\begin{array}{l}\text { "Minimal" } \\
\text { housing estates }\end{array}$ & \\
\hline
\end{tabular}

Source: (Aduar Group, 2000).

Most of this kind of housing was built during the 1950's and 1960's, at a time when profound changes were taking place in Spanish society. Such changes must be understood within the context of the implementation of a Stabilisation Scheme which brought about the reinforcement of the capitalist system and the concentration of the means of production, as well as the intensification of the economic activity. This resulted in a notable increase of industrial production and the internal migration of 3.5 million people from rural areas into urban ones that required abundant workforce. Although at the beginning this situation fa- 
voured only Madrid and Barcelona, soon new measures were implemented which allowed a more fairly distributed industrial growth: the so called "Development Plans", the aim of which was to promote the industrialisation of all Spanish regions.

The sheer magnitude of this urban demographic growth brought about by the shift of economy and society towards the tertiary sector forced Spanish public authorities to take action in the construction of dwellings for the less privileged sectors of society in the face of the housing shortage. The difficulties a large number of people came across to access adequate housing entailed the risk of poor quality buildings mushrooming everywhere, that is, of social exclusion. This kind of measures meant that the construction was carried out in its integrity by the public authorities, from the purchase of land through to the final delivery of the dwellings, always with the aim of benefiting the less privileged sectors of society.

By way of an indication of the importance this kind o initiatives had, I shall mention that in Madrid over 100.000 state-fostered dwellings were built between 1940 and 1976 (Aduar Group, 2000). The urbanising process implied a growth of $30 \%$ in urban population, percentage that grew to $66.1 \%$ in 1970 .

\section{HOUSING ESTATES: A MODEL OF RATIONALISTIC TOWN-PLANNING}

One of the most representative urban elements of this fast-development period were the housing estates, residential complexes of collective housing. There is a large number of them throughout the whole of Spain. Madrid and Barcelona have the largest number and the largest in size, with San Blas and La Mina among the most salient ones. Nevertheless, although on a lesser scale, we find good examples in Seville with the 3000 viviendas (“3000 dwellings"), A Coruña with Elviña, Santiago de Compostela with Vite and Gijón with El Llano, etc.

In spite of being in such distant places, all of them have a common denominator which makes them easily identifiable:

- They are generally located on the outskirts of cities or metropolitan areas, and find support on former villages. In this sense, one must bear in mind that it was on the outskirts of cities where extensive areas could be found to carry out such large-scale urban developments, as well as much cheaper land prices and low final building costs; besides, urban ordinances were not so strict there. The fact that these new estates were built in the vicinity of former villages resulted in their inhabitants having the impresssion of living totally cut off from the already consolidated urban areas.

- They have clear boundaries and clear access roads, in such a way that they can be clearly spotted on the map and their limits are perfectly identifiable by both their inhabitants and the inhabitants of other areas.

- Their network of roads is perfectly structured hierarchically by means of a set of ring roads, distribution roads and dead-end streets used for parking.

- They are mostly concentrations of open-space residential buildings, built according to the rationalistic tenets of Le Corbusier, who propounded the concentration of dwellings 
in tower blocks to allow for more space available for a contact with nature. This model of communal city was conceived within the framework of a wider urban and sociologic philosophy, which considered urban space as the superposition of communities at several levels, starting with neighbourhood units as the smaller components. These neighbourhoods housed around 5 to 6 thousand people, had communal services and facilities and, together with other neighbourhoods grouped together to form quarters which, in turn, formed cities. The intention behind it was to recover social interaction, which had been lost in large industrial cities.

- Most estates were composed of rectangular blocks, although in other cases these were combined with high rise tower blocks or with detached houses, such as was the case with Elviña. In this case, access to one kind of dwelling or another was determined by family income and by the number of household members. In this way, families with fewer members and smaller incomes occupied the blocks of flats, whereas those with higher incomes and more members occupied the tower blocks and the detached houses.

- They usually have high building densities both because of the number of blocks built in each estate and because of the number of floors in each block and flats on each floor. In some cases, a slope in the land was used to increase the number of floors, in such a way that one side of the building may have four floors starting from a horizontal plain occupied by shops, while as the slope descends towards the lower plain, more floors are added. As a result, a block of flats with 5 floors on one side, may be as high as 11 floors on the other.

- Building materials are of very poor quality. Subsequently, the facades are very deteriorated and in many of them one can see the piping of the first floor. In general, their occupants have not bothered to invest any money in improving the external appearance of the blocks, as many of them do not own their flats yet. One must bear in mind that the tenants of those dwellings paid a lease of 3 euros or less, and that they could purchase them after a period of 50 years. In the 1980's, the governments of the different autonomous regions in Spain, which had then taken charge of the aforesaid dwellings, gave tenants the opportunity to purchase them for their original price, but not too many people chose to do it. Moreover, sometimes, as is the case with the estate in Seville known as the "3000 viviendas", there are places which are practically irrecoverable, as the damage undergone by the dwellings was too extensive (there are no windows, the piping has been ripped out to be sold, etc.).

- The intention was for these city quarters to become small autonomous urban units with a life of their own and with enough shops to satisfy basic needs so that people did not have to travel to the town centre. The Elviña housing estate and, more specifically, the so called Barrio de las Flores or ("town quarter of the flowers"), was a good example of such autonomy. Nevertheless, that aim was not fulfilled in most estates.

- They originally lacked public transport and other services, which provoked their segregation from the rest of the city. At present, some of them do not have rubbish collection services or policing, as they are beset by delinquency.

- Although at the beginning they were laid out with gardened areas, in a rationalistic fashion, the urge to maximise the use of each square metre caused the lack of green 
recreational areas in estates such as that of Seville, the result being a grey mass of concrete without open spaces. In many cases, promoters were allowed to breach their obligations to urbanise or transfer the land, and they limited themselves to doing the essential and selling the dwellings.

\section{OUTSIDE IMAGE AND SOCIAL CONFLICTS}

As we said before, these estates are characterised by a common urban morphology. Moreover, from a sociological point of view, we can also find in them a set of common behavioural patterns:

- All of them were built for low and middle-income social sectors. However, we must differentiate between the Tres Mil Viviendas estate and those of Elviña or Vite. The former was designed as a residential area for the destitute families of the city, often crammed in precarious flats, most of them gypsies, with serious problems of segregation and social exclusion. In the case of the latter two, on the other hand, although they were occupied by low-income social sectors, their economic situation was better than that of the residents in the Seville estate.

- The falangist notion that class distinctions were not going to exist in them was a total failure. Gradually residents began to establish differences between them to the extent that eventually every estate has ended up having a certain area that seems to gather a sector of the population with the worst problems of social integration owing to delinquency and drug-addiction.

- However, there is a curious feeling of neighbour solidarity among the inhabitants of these estates. Generally, neighbours living in the same block of flats know one another and offer help in times of difficulty. There is a sharp sense of belonging to the place, which results in respect towards the other neighbours. By way of example, we can point out that, in Elviña, delinquents did not rob the shops in the estate or attack its inhabitants, but went to the neighbouring city quarters to commit their offences.

- In them, delinquency and drug-addiction were the most serious problems. The police did not dare patrol them and it was very difficult to maintain order since, occasionally, the lay-out of the estate favoured the flight of youngsters who were found selling drugs or involved in acts of vandalism, since patrol cars kept coming across dead-end alleys which did not allow the chase. Moreover, continued street rows resulted in the police not paying any attention to calls and abandoning those who provoked them to their own devices.

All the above factors turned these estates into zones of social exclusion, stigmatised in a way difficult to overcome due to the very negative image the rest of inhabitants of the city have of them, to the extent that they avoid them totally. However, that negative perception does not match up with the opinion held by those who live in an estate themselves, as they consider that the situation is not so serious and that there is no risk involved in strolling across them, as is put by a former resident of the Tres Mil Viviendas estate: "I left the estate about three years ago, and although it may be one of the areas with higher levels of delin- 
quency, unemployment, drug-addiction and so on, it is not as bad as people make it out, and I think one must actually live there to know what it is like. We are happy, sing and dance, because it goes in our blood, however people do not take any heed of that, but focus on the needs that the southern area of the estate has. By the way, I have neighbours and nobody has complained about my family. I am a gypsy and very proud of it too: I have been educated and now how to behave in a community".

During the past few years, steps have been taken to improve the social conditions and inhabitability of the estates. Nevertheless, from a social point of view and image-wise each one has its own different situation:

Tres Mil Viviendas Estate (Seville): the original pursuit of the social integration of the residents of this estate was a complete failure, since the fact that they were provided with a dwelling was not reinforced by any kind of measures to offer them a change of occupation or an increase of their living standards, in such a way that lack of culture and shortage of financial means provoked the fast deterioration of buildings and communal facilities, which was accompanied by the problem of drug-addiction among youngsters, and by episodes of delinquency. All of the above led to this estate becoming an unsafe zone and a ghetto the boundaries of which nobody dared trespass, a place whose inhabitants could hardly move out of owing to their precarious economies, and into which nobody wanted to move. This situation has created a negative perception which transcends the city of Seville itself, the estate being perceived nation-wide as a dangerous, conflictive place.

Actually, lack of safety and drug-addiction do exist and many public services have been discontinued (rubbish collection, public lighting, etc.), but not the whole of the estate has the same characteristics, since only 600 out of the 3,000 dwellings house conflictive people and the rest are inhabited by low-income people who are trying to fight against the negative image the estate has to endure through neighbours' associations which are seeking to obtain public and private funds in order to change the direction of things. This area was left to its own devices until the mid-1990's, when an ambitious reintegration scheme was set in motion supported by substantial investments. Its aim was to persuade youngsters to give up drugs and offer them training and education so that they could earn themselves a living. In the region of 20 million euros a year have been invested in occupational training schemes for youngsters, in a social reinsertion programme, as well as in different attempts to improve the degraded habitat of the southern sector of the estate, with hardly any results so far, since the drive to earn easy money through small-scale drug pushing prevails and also because in marginal communities a change of living is considered pointless, as the rest of society look at it with suspicion.

Among the initial reports of the General Urban Scheme for Seville (2002) there is a survey on people's intention to move into a new dwelling, and in the Southern District, which comprises other city quarters besides that of the Tres Mil Viviendas ("three thousand dwellings"), $50.5 \%$ of their population claim to intend to move out of there as soon as they can, the main reasons being the derelict state of the area, the dissatisfaction caused by living amidst social conflict and the negative perception the rest of the city has of it. Those surveyed claim that they will move out as soon as an affordable opportunity arises. But, obvi- 
ously, in most cases that will never happen, and they will keep putting off their intention, which is more of a dream than a reality.

In contrast, in medium-size cities, the situation is different since, although they initially suffered the problems of lack of safety and drug-addiction, these were eventually overcome and estates have turned into acceptable residential and recreational areas due to the green areas surrounding them:

Barrio de Vite-Vista Alegre and Elviña: during the 1980's, these estates started to deteriorate and to suffer certain delinquency problems related to drug-addiction which hit hard the adolescent children of the families who had moved into the area during the previous decade. For this reason, the dwellers of other areas of the city avoided these estates as far as possible, above all after the evening came, as they were perceived as unsafe areas. This situation changed gradually and improved notably from the early 1990's onwards. Three were the most salient contributing factors:

- The disappearance of that conflictive generation, not because of the effect of any social reintegration or drug-use eradication measures had been implemented, but because many of them died.

- The fact that many young adults emancipated and moved into other areas of the city.

- The establishment of university campuses and cultural facilities nearby in the case of Vite or the building of quality residential areas in their vicinity, as was the case with Elviña.

As a result of this new situation, there is a growing care for looking after these estates apparent in the creation and good maintenance of green areas which have turned them into attractive residential options, as their residents enjoy the peace and quiet of wide recreational areas difficult to find elsewhere in the city. Besides, the death of many elderly people has resulted in their inheritors putting their flats for sale for affordable prices, and many young married couples are moving into these estates. In the case of Vite, the situation in somewhat different as it was not built and inhabited until comparatively later (until the late 1970's), their dwellers are not as old and therefore there flats are not out on the market yet.

\section{CURRENT SITUATION}

The different situations we have just seen among estates of similar constructive characteristics in the medium-size cities of Santiago and A Coruña and the large city of Seville, involve the existence of quite different demographic characteristics. Thus, in Seville, in the case of the Tres Mil Viviendas Estate, we find a very young population pyramid (figure 1), in spite of it being an area which has received very few new residents from the time of its construction, over two decades ago. What is happening now is that a large proportion of the children of those who originally came to live there are having their offspring now, and they continue to live in the same flat as their parents, in such a way that the density of population is growing, thus aggravating the existing inhabitability problems. Besides, social exclusion is accentuated by the fact that unemployment affects over a third of the workingage population. Among those employed, many work in the construction industry (among 
males) and in unskilled jobs in the service sector. This is the area of Seville with lowest educational levels, as $6.6 \%$ of its population are illiterate and $70.4 \%$ have not completed any formal schooling. Only $17.6 \%$ have a primary education diploma or basic polytechnic training. Very few have completed their secondary education (3.9\%) or university studies $(1.5 \%)$.

Figure 1: Population pyramids of three housing estates.

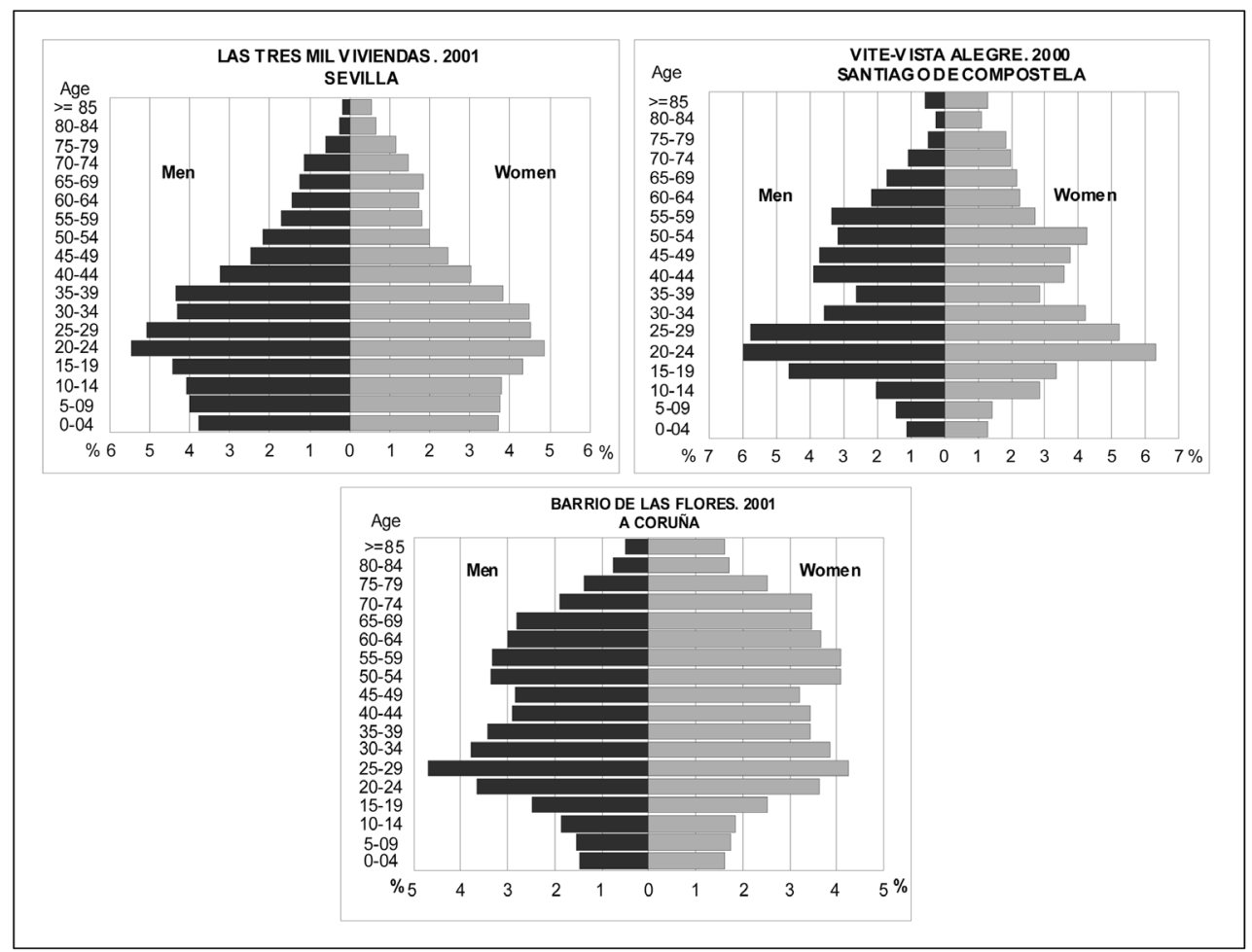

The demographic and socio-professional structure of the inhabitants of Vite-Vista Alegre in Santiago de Compostela is very different, as this area was occupied in the late 1970's by young married couples who already had young children or who had some children shortly after moving into the estate. The population has not increased since then, and most of these married couples are now in the age range of 40 to 59, outside the ages of maximum fertileity, and their children are now in the age range of 15 to 29. Once emancipated, youngsters have moved to other areas of the city and the birth rate there has dropped dramatically in such a way the average number of household members is decreasing. The loss the relative weight of the population of young adults and adolescents and the improvement of the standard of living among the inhabitants of this estate in comparison with the moment they first moved there has resulted in it being better regarded, besides delinquency and drug abuse have disappeared. Moreover, unemployment levels have decreased from $25 \%$ of the work- 
ing-age population (mostly among youngsters) in the late 1980 's to $13 \%$ nowadays. A large part of the employed population work in shops or in catering $(30 \%)$, although unskilled jobs are also abundant (15\%) as well as jobs in the construction industry among males $(32 \%)$. Educational levels, although not too high, have nothing to do with those found in the case of Seville, which we have just seen, with $3.9 \%$ of illiterates, $39.2 \%$ without formal education, $33.6 \%$ with a compulsory schooling diploma or equivalent and $23.3 \%$ having completed their secondary education or university studies.

The situation is totally different in the Barrio de las Flores estate. A demographic analysis reveals that the average age of its residents has increased, to the extent that the population pyramid has acquired the shape of an amphora, with a narrow base reflecting the low birth rate detected, a predominance of adults and a considerable percentage of residents aged 65 or over.

This has happened owing to the fact that, from the start, the estate was occupied by not-too -young married couples with young children, or whose children where born there a few years later. These children are now adults who appear reflected in the age band from 29 to 34 . On the other hand, although the estate is currently receiving young couples who find affordable flats in it, the demographic situation has not reached a balance, and the trend is that the average age of residents will continue to rise in the future.

\section{CONCLUSION}

Housing Estates were built both in medium-size cities and large ones, although the timing was different as a result of the different pace of the industrialisation process in different areas.

They are conflictive areas of exclusion which, in the case of medium-size towns, are undergoing a change of image thanks to training and social reintegration schemes. In contrast to that, in the case of large cities, owing to the dissimilar cultural roots of the population occupying the estates and to the degree of conflictivity existing in them, betterment programmes are not being as effective as hoped.

Some estates in medium-size cities are improving their image, as some improvements are being introduced in terms of facilities, green areas, etc. and they are not perceived as dangerous any more, but quite the opposite; however, in large towns these estates are still no-go urban areas.

\section{References}

Aldrey Vázquez, J. A., 1999: Análise da poboación na área urbana de Santiago de Compostela. Consorcio de Santiago. Santiago de Compostela.

Avance plan de ordenación urbana de Sevilla, 2002. www.plandesevilla.org.

Fernández Anta, D. Lopez Portero, E., Lucas Viña, M. L. La vivienda en Madrid 19391961. Madrid. www.ucm.es/info/hcontemp/madrid/Introducción. 
Lopez Díaz, J., 2003: Vivenda social y falange: ideario y construcciones en la década de los 40. Barcelona. www.ub.es/geocrit/sn/vlopedi.htm.

Oikos, 1975: "Notas sobre el desarrollo urbano de Santiago en la década de los sesenta". En, Ciudad y Territorio. No 1 e 2, Enero-Junio. Madrid. 95-106.

Terán, F. De, 1999: Historia del Urbanismo en España III. Siglos XIX y XX. Madrid.

Zoido, F.; Vega, S. de la; Morales, G.; Mas, R.; Y, Lois, R. C., 2000: Diccionario de Geografía Urbana, Urbanismo y Ordenación del Territorio. Ariel Referencia. Barcelona. 